\title{
Role of Recombinant Parvalbumin Gad c 1 in the Diagnosis and Prognosis of Fish Allergy
}

\author{
Carvalho S1', Marcelino J', Cabral Duarte MF¹, Costa C¹, Barbosa MA ${ }^{1}$, Pereira Dos Santos MC ${ }^{2}$ \\ 'Imunoallergology Department, Centro Hospitalar Universitário Lisboa Norte, Hospital Santa Maria, Lisbon, Portugal \\ ${ }^{2}$ Clinical Immunology Unit - Instituto de Medicina Molecular, Faculdade de Medicina - Universidade de Lisboa, Lisbon, Portugal
}

J Investig Allergol Clin Immunol 2020; Vol. 30(5): 340-345

doi: 10.18176/jiaci.0437

\begin{abstract}
Background: The prevalence of fish allergy has increased in recent years. The parvalbumin Gad c 1 is a major cod allergen that is used as a follow-up marker in patients with fish allergy.

Objectives: To determine the clinical and laboratory characteristics of a population of patients with fish allergy. To analyze the role of the specific lgE (slgE) of recombinant Gad c 1 ( $\mathrm{rGad}$ c 1) and skin prick tests (SPTs) in confirming the acquisition of tolerance to fish.

Methods: We performed a retrospective study of patients with fish allergy from July 1, 2005 to December 31, 2016. The population was characterized according to demographic data, species of fish associated with allergic reactions, and symptoms. The SPT wheal diameter and slgE for fish and rGad c 1 were evaluated before acquisition of tolerance (TO) and afterwards (T1).

Results: The study population comprised 81 patients (68\% male). Most reactions were triggered by hake $(51 \%)$, mackerel $(30 \%)$, and $\operatorname{cod}(26 \%)$. The most frequent manifestations were urticaria/angioedema (72\%), gastrointestinal symptoms (35\%), and eczema (33\%); $42 \%$ of patients experienced anaphylaxis. At TO, the average slgE values were as follows: cod, $32.2 \mathrm{kU} \mathrm{A}_{\mathrm{A}} / \mathrm{L}$; sardine, $18.4 \mathrm{kU} / \mathrm{L}$; hake, $17.5 \mathrm{kU}_{\mathrm{A}} / \mathrm{L}$; salmon, $13.9 \mathrm{kU}_{\mathrm{A}} / \mathrm{L}$; tuna, $4.5 \mathrm{kU}_{\mathrm{A}} / \mathrm{L}$; and $\mathrm{rGad} \mathrm{c} 1,22.9 \mathrm{kU}_{\mathrm{A}} / \mathrm{L}$. In patients who acquired tolerance to at least 1 fish species $(\mathrm{n}=60 ; 74 \%)$, the mean value of $\mathrm{rGad} \mathrm{c} 1$ at $\mathrm{T1}\left(5.1 \mathrm{kU}_{\mathrm{A}} / \mathrm{L}\right)$ was significantly lower than at $\mathrm{T0}(16.8 \mathrm{kU} / \mathrm{L})(P=.001)$. Significant values were also recorded for the average diameter of the SPT wheal and the evaluations at T0 and T1 for hake $(9.42 \mathrm{~mm} / 3.79 \mathrm{~mm})$ and salmon (7.8 mm/2.8 mm) $(P=.002$ and $P=.026$, respectively).

Conclusion: The decrease in slgE to rGad c 1 and the mean wheal diameter of SPT for hake and salmon can be used as markers of prognosis in the acquisition of tolerance by fish-allergic patients.
\end{abstract}

Key words: Food allergy. Fish allergy. Parvalbumin. Cross-reactivity. Recombinant allergen. rGad c 1.

\section{Resumen}

Antecedentes: La prevalencia de alergia al pescado ha aumentado en los últimos años. Gad c 1 es una parvalbúmina y un importante alérgeno del bacalao, utilizado como marcador de seguimiento en pacientes con alergia a pescado.

Objetivos: Caracterización clínica y de laboratorio de una población de pacientes con alergia a pescados. Analizar la contribución de la IgE específica (slgE) a parvalbúmina recombinante ( $\mathrm{rGad}$ c 1) y las pruebas cutáneas (SPT) para confirmar la aparición de tolerancia al pescado. Métodos: Estudio retrospectivo de pacientes con alergia a pescados, desde julio de 2005 hasta diciembre de 2016. Se recogieron datos demográficos, reacciones alérgicas y síntomas con los pescados; el diámetro total de la SPT y el valor de la lgE a rGad c 1 antes (T0) y después de la adquisición de tolerancia (T1).

Resultados: Se evaluaron 81 pacientes (68\% hombres). La merluza (51\%), caballa (30\%) y bacalao (26\%) desencadenaron la mayoría de las reacciones. Las manifestaciones más frecuentes fueron urticaria/angioedema (72\%), síntomas gastrointestinales (35\%) eccema (33\%) y el $42 \%$ de los pacientes tuvieron anafilaxia. En (TO), los valores medios de slgE fueron: bacalao $\left(32,2 \mathrm{kU}_{\mathrm{A}} / \mathrm{L}\right)$, sardina $(18,4 \mathrm{kU} / \mathrm{L})$, merluza $\left(17,5 \mathrm{kU}_{A} / \mathrm{L}\right)$, salmón $\left(13,9 \mathrm{kU}_{\mathrm{A}} / \mathrm{L}\right)$, atún $\left(4,5 \mathrm{kU}_{\mathrm{A}} / \mathrm{L}\right)$ y rGad c $1\left(22,9 \mathrm{kU}_{\mathrm{A}} / \mathrm{L}\right)$. En pacientes que adquirieron tolerancia a al menos una especie de pescado $(n=60 ; 74 \%)$, el valor medio de $\mathrm{rGad}$ c 1 en T1 $\left(5,1 \mathrm{kU}_{\mathrm{A}} / \mathrm{L}\right)$ fue significativamente más bajo que T0 (16,8 $\left.\mathrm{kU} / \mathrm{L}\right)$ $(\mathrm{p}=0,001)$. Los valores del diámetro medio de la SPT en T0 y T1 para merluza $(9,42 \mathrm{~mm} / 3,79 \mathrm{~mm})$ y salmón $(7,8 \mathrm{~mm} / 2,8 \mathrm{~mm})$ también fueron significativos $p=0,002$ y $p=0,026$, respectivamente.

Conclusión: La disminución de la slgE a rGad c 1 y el diámetro medio de la SPT para merluza y salmón se pueden utilizar como marcadores de pronóstico en la adquisición de tolerancia de alergia a pescados.

Palabras clave: Alergia a alimento. Alergia a pescado. Parvalbúmina. Reactividad cruzada. Alérgeno recombinante. rGad c 1. 


\section{Introduction}

The frequency of allergic diseases has been rising in most industrialized countries, and the World Allergy Organization has reported that $20 \%$ to $30 \%$ of the world population is affected by allergy [1].

The highest fish consumption in Europe is in Scandinavia, Spain, and Portugal [2]. The high nutritional value of fish and its association with a healthy diet have led to an increase in consumption worldwide, thus explaining the increased frequency of reactions to fish, particularly allergic reactions [3-7].

The first reported cases of fish allergy date back to 1930 , when De Besque et al reported cases of allergic reactions with ingestion, contact, and inhalation of fish allergens $[1,2,8]$. However, the most common sensitization route is through the gastrointestinal tract $[1,2,9]$.

Fish allergy is the third most common food allergy in Europe after milk and egg allergy [2]. The prevalence of fish allergy (self-reported) ranges from $0.2 \%$ to $2.29 \%$ in the general population but may be more than $8 \%$ in specific populations, such as fish processing workers [1].

Fish allergy usually develops in early childhood, when fish is first introduced to the diet, although unlike milk or egg allergy, it continues to affect about $80 \%$ of patients, even 10 years after the initial diagnosis [2,3]. Fish allergy can also develop in adulthood [5].

While most allergic reactions to fish are IgE-mediated [2,4,9], non-IgE-mediated fish allergy, such as food protein-induced enterocolitis syndrome, has been reported [2]. According to a Spanish study of 355 children with fish IgE-mediated allergy, this type of allergy first appears before the second year of life [2].

Fish allergy is a multiorgan disease, and patients may display symptoms compatible with oral allergy syndrome, rhinitis, urticaria, angioedema, bronchospasm, exacerbations of atopic dermatitis, and gastrointestinal symptoms (eg, abdominal pain, nausea, vomiting, and diarrhea). Anaphylaxis may occur in more severe cases $[1,2,4,5,8,9]$.

Parvalbumin was first recognized as a panallergen of fish in the 1970s $[1,2,10]$. This low-molecular-weight protein $(10-12 \mathrm{kDa})$ is present in fish muscle fibers $[5,9,10]$. While parvalbumin is the major fish allergen in most patients presenting parvalbumin-specific $\operatorname{IgE}(70 \%$ to $100 \%)[5,10]$, little attention has been given to other allergens, such as enolase, aldolase, and collagen [5], which are less concentrated in fish and whose relevance as food allergens is not yet fully understood $[1,9,10]$.

Fish muscles are composed of 2 types of fibers - white/ light or red/dark - depending on their function and myoglobin content. Parvalbumin concentrations are higher in white fibers $[3,8,9]$. Species such as tuna, skipjack, and swordfish have a higher proportion of dark fibers than species such as cod, flounder, and hake, making them a hypothetically more allergenic species [3]. Parvalbumin is particularly stable (resistant to heat and chemical desaturation, as well as to the action of proteolytic enzymes) $[1,3,5,10]$, which means that even cooked fish maintains its allergenicity [2].

Cross-reactivity between fish species can be explained by the extensive homology between parvalbumins of different species (60\%-80\%) [1,3,4,6,9-11]. Most fish-allergic patients $(67 \%)$ do not tolerate various fish species, probably owing to parvalbumin cross-reactivity $[1,6,10]$. More recently, however, cases of monosensitization have been reported, and some patients tolerate only specific fish $[1,5,6,8,9,12,13]$.

Allergy to cod has been studied extensively, and most fishallergic patients develop symptoms with cod. Furthermore, IgE has a higher affinity for cod parvalbumin ( $\mathrm{Gad} \mathrm{c} 1)$ than for other fish parvalbumins, making it one of the best studied parvalbumins $[1,4,8,10]$.

The gold standard diagnostic method in fish allergy is the oral provocation test [1]. Provocation testing can be preceded by skin prick tests (SPTs) with commercial extracts and the food itself, which are a quick and safe way to evaluate patients with a history suggestive of fish allergy. The initial study of these patients is completed by performing $\operatorname{IgE}$ assays for parvalbumin and for each fish species [5]. It is accepted that a lower level of $\mathrm{IgE}$ for a particular fish is associated with less probability of reaction and less severe reactions [1]. Studies to determine serum specific $\operatorname{IgE}$ (sIgE) cut-offs for the diagnosis of fish allergy show that $\operatorname{sIgE}>20 \mathrm{kU}_{\mathrm{A}} / \mathrm{L}$ for $\mathrm{Gad} \mathrm{c} 1$ is diagnostic of fish allergy (95\% confidence) [9].

The only recommended treatment is avoidance, although this is not always possible [1,3]. While allergy to fish is considered a lasting allergy, there have been cases of patients who become tolerant to fish after an avoidance diet $[1,9]$. On the other hand, studies carried out with hypoallergenic parvalbumin point to allergen immunotherapy as an increasingly viable possibility $[7,9,10,14]$.

The aim of this study was to determine the clinical and laboratory characteristics of patients diagnosed with fish allergy followed in our department by evaluating their sensitization profile to different fish. We also analyzed the contribution of SIgE for recombinant parvalbumin Gad c $1(\mathrm{rGad} \mathrm{c} 1)$ and of SPTs in the diagnosis and prognosis of fish-allergic patients.

\section{Methods}

\section{Study Population}

We performed a retrospective analysis of 81 fish-allergic patients followed in our Immunoallergology Department from July 1, 2005 to December 31, 2016. The diagnosis was confirmed by clinical history, positive skin prick-test results, and specific IgE determinations.

The population was characterized according to demographic data and type of fish associated with the reaction and symptoms.

The results of the SPTs with commercial extracts (Bial Aristegui) and sIgE to various fish species and $\mathrm{rGad}$ c 1 (lmmunoCAP, Thermo Fisher Scientific) at the time of diagnosis were analyzed in all patients at baseline (T0).

SPTs and sIgE to rGad c 1 and other fish species were evaluated and compared after the acquisition of tolerance (T1) in the group that achieved tolerance to at least 1 fish species, as confirmed by oral challenge or spontaneous ingestion at home.

\section{Statistical Analysis}

The Wilcoxon signed rank test was used to compare levels of sIgE for rGad c 1 and several other fish species before and after acquisition of tolerance to at least 1 species, as well as to compare the SPT wheal diameters. A $P$ value $<.05$ was considered statistically significant. 
Table 1. Characteristics of the Study Population

\begin{tabular}{lcc}
\hline & No. & $\%$ \\
\hline Total Patients & 81 & $100 \%$ \\
Gender & & \\
$\quad$ Male & 55 & 67.90 \\
$\quad$ Female & 26 & 32.10 \\
Atopic Background & 75 & 92.60 \\
$\quad$ Rhinitis & 63 & 77.78 \\
$\quad$ Eczema & 54 & 66.67 \\
$\quad$ Asthma & 35 & 43.21 \\
First symptoms $<18$ y & & \\
Mean age, 24.2 $(31.1)$ mo & 77 & 95.06 \\
First symptoms $>18$ y & & \\
Mean age, $37.8(13.0)$ y & 4 & 4.94 \\
\hline
\end{tabular}

The statistical analysis was performed using SPSS (Version 23.0) and Excel (Microsoft Office 2016).

\section{Results}

\section{Characterization of the Study Population}

The study population comprised 81 patients (68\% male, $32 \%$ female), 75 of whom (93\%) were atopic. We recorded rhinitis in $63(78 \%)$ patients, eczema in $54(67 \%)$, and

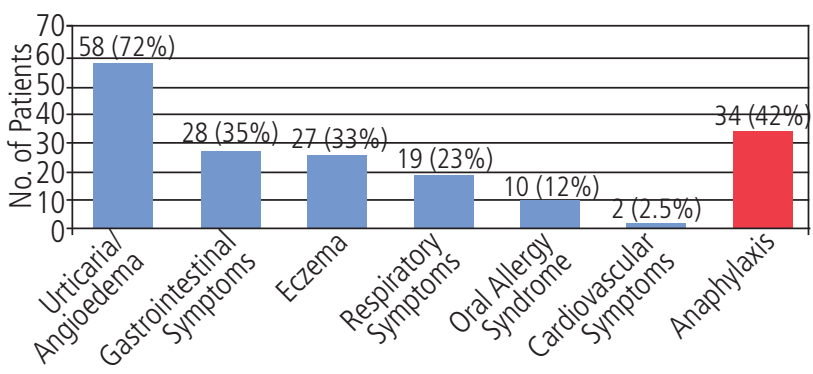

Figure 1. Clinical manifestations associated with contact with fish.
Table 2. Species of Fish Associated With Allergic Reactions

\begin{tabular}{lcc} 
& No. & $\%$ \\
\hline Hake & 41 & 50.62 \\
Mackerel & 24 & 29.63 \\
Codfish & 21 & 25.93 \\
Gilt-head bream & 17 & 20.99 \\
Sardine & 16 & 19.75 \\
Halibut & 15 & 18.52 \\
Salmon & 14 & 17.28 \\
Fresh tuna & 12 & 14.81 \\
Redfish & 11 & 13.58 \\
Seabass & 11 & 13.58 \\
Swordfish & 9 & 11.11 \\
Perch & 7 & 8.64 \\
White grouper & 7 & 8.64 \\
Croaker & 6 & 7.41 \\
Whiting & 6 & 7.41 \\
Canned Tuna & 5 & 6.17 \\
Flatfish & 5 & 6.17 \\
Ling & 5 & 6.17 \\
Croup & 1 & 1.23 \\
\hline
\end{tabular}

asthma in $35(43 \%)$. Seventy-seven patients (95\%) developed symptoms before the age of 18 years (mean age, 24.2 [31.1] months) and 4 (5\%) after the age of 18 (mean age, 37.8 [13.0] years) (Table 1).

The 5 most common fish species associated with allergic reactions were hake (41 [51\%]), mackerel (24 [30\%]), codfish (21 [26\%]), gilt-head bream (17 [21\%]), and sardine (16 [21\%]) (Table 2).

Mean age at first contact with fish was 9 months. In 50\% of patients, symptoms compatible with allergic reaction appeared during the first ingestion.

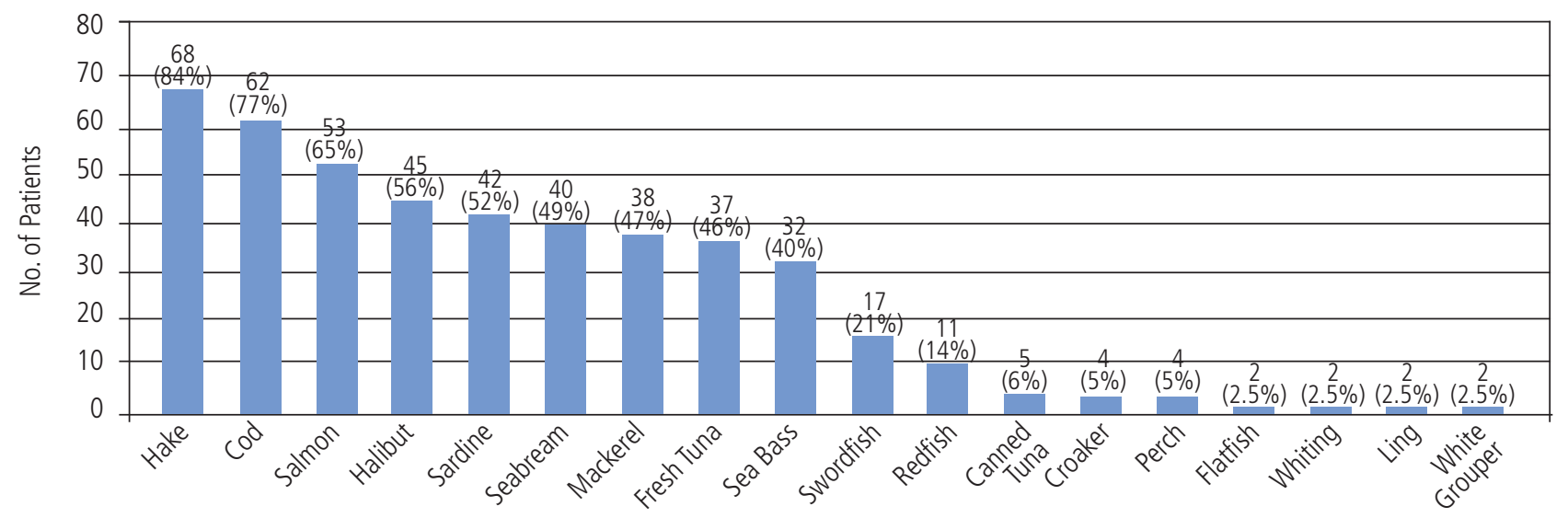

Figure 2. Positive results for skin prick tests performed with several fish species. 
Four $(5 \%)$ patients experienced an allergic reaction to all of the species, although only 1 was monosensitized to redfish. The remaining patients did not tolerate a mean of 2.9 (3.8) fish species.

Patients presented symptoms not only with fish intake $(78,96 \%)$, but also, albeit to a lesser extent, after skin contact (22 [27\%]) and inhalation of cooking vapors (16 [20\%]). Anaphylaxis manifested in 34 patients (42\%). Considering only clinical manifestations, the frequency of symptoms associated with fish contact were urticaria/angioedema (58 [72\%]), gastrointestinal symptoms (28 [35\%]), and eczema (27 [33\%]). However, some of these patients, also presented respiratory symptoms (19 [23\%]), oral allergy syndrome (10 [12\%]), and cardiovascular symptoms (2 [2.5\%]) (Figure 1).

\section{Skin Prick Tests and Specific IgE}

All patients underwent SPTs with commercial extracts of various fish species at T0 and were positive for at least 1 fish species (Figure 2).

The mean wheal diameter in the SPT at T0 was $9.4 \mathrm{~mm}$ to hake, $9.3 \mathrm{~mm}$ to cod, $9.1 \mathrm{~mm}$ to sardine, $7.8 \mathrm{~mm}$ to salmon, and $4.8 \mathrm{~mm}$ to tuna.

The mean sIgE values at T0 were as follows: cod, $32.2(40.8) \mathrm{kU}_{\mathrm{A}} / \mathrm{L}$; sardine, 18.4 (32.0) $\mathrm{kU}_{\mathrm{A}} / \mathrm{L}$; hake, 17.5 (31.4) $\mathrm{kU}_{\mathrm{A}} / \mathrm{L}$; salmon, 13.9 (25.5) $\mathrm{kU}_{\mathrm{A}} / \mathrm{L}$; halibut, 9.1 (21.6) $\mathrm{kU}_{\mathrm{A}} / \mathrm{L}$; tuna, 4.5 (6.9) $\mathrm{kU}_{\mathrm{A}} / \mathrm{L}$; and $\mathrm{rGad} \mathrm{c} 1$, $22.9(34.9) \mathrm{kU}_{\mathrm{A}} / \mathrm{L}$ (Table 3).

\section{Acquisition of Tolerance}

Sixty of the 81 study patients (74\%) acquired tolerance to at least 1 fish species.

The most and earliest tolerated species was tuna (51 patients [63\%]), followed by cod (20 [25\%]), salmon (20 [25\%]), hake (18 [22\%]), gilt-head bream (14 [17\%]), mackerel (13 [16\%]), swordfish (13 [16\%]), sardine (12 [15\%]), halibut (11 [14\%]), perch $(9[11 \%])$, sea bass $(8[10 \%])$, whiting (7 [9\%]), white grouper (7 [9\%]), croaker (6 [7\%]), flatfish (6 [7\%]), ling (6 $[7 \%])$, and redfish (5 [6\%]).

The mean age at acquisition of tolerance was 10.5 (10.2) years. Five patients ( $8 \%$ ) acquired tolerance to all fish species, which was confirmed by oral food challenge.

For the patients who acquired tolerance to at least 1 species, the mean rGad c $1 \mathrm{sIgE}$ value at T0 was $16.9 \mathrm{kU} / \mathrm{L}$, which was significantly lower than at $\mathrm{T} 1$, with an average value of $5.1 \mathrm{kU}_{\mathrm{A}} / \mathrm{L}(P=.001)$.

Table 3. Mean Values of slgE at First Evaluation for Several Species of fish

\begin{tabular}{lc}
\hline Species & Mean Values, $\mathrm{kU}_{\mathrm{A}} / \mathrm{L}$ \\
\hline Cod & $32.2(40.82)$ \\
Sardine & $18.4(32.03)$ \\
Hake & $17.5(31.44)$ \\
Salmon & $13.9(25.46)$ \\
Tuna & $4.5(6.90)$ \\
Halibut & $9.1(21.55)$ \\
rGad c 1 & $22.9(34.99)$
\end{tabular}

Table 4. Average Values of Wheal Diameters in Skin Prick Tests and Average Values of slgE to rGad c 1 and Several Fish Before (TO) and After Acquisition of Tolerance (T1) to at Least 1 Fish Species

\begin{tabular}{lccc} 
& $\begin{array}{c}\text { Before } \\
\text { Acquisition of } \\
\text { Tolerance (T0) }\end{array}$ & $\begin{array}{c}\text { After } \\
\text { Acquisition of } \\
\text { Tolerance (T1) }\end{array}$ & $\begin{array}{c}P \\
\text { value }\end{array}$ \\
\hline Average wheal diameter, mm & & \\
Cod & 9.33 & 3.43 & .066 \\
Tuna & 4.82 & 3.40 & .180 \\
Hake & 9.42 & 3.79 & .002 \\
Salmon & 7.78 & 2.75 & .026 \\
Sardine & 9.07 & 2.50 & .180 \\
Average values of sIgE, $\mathrm{kU}_{\mathrm{A}} / \mathrm{L}$ & & \\
rGad c 1 & 16.85 & 5.07 & .001 \\
Cod & 18.60 & 10.21 & .0007 \\
Tuna & 2.63 & 2.61 & .101 \\
Hake & 5.56 & 5.23 & .016 \\
Salmon & 16.15 & 3.87 & .001 \\
Sardine & 5.29 & 4.67 & .004 \\
\hline
\end{tabular}

Mean IgE values were analyzed for several species (cod, hake, salmon, sardine, and tuna) at T0 and T1 for patients who acquired tolerance to at least 1 species. Mean IgE values were significantly lower at $\mathrm{T} 1$ for $\mathrm{rGad} \mathrm{c} 1\left(5.07 \mathrm{kU}_{\mathrm{A}} / \mathrm{L}\right)$, cod $\left(10.2 \mathrm{kU}_{\mathrm{A}} / \mathrm{L}\right)$, sardine $\left(4.7 \mathrm{kU}_{\mathrm{A}} / \mathrm{L}\right)$, hake $\left(5.23 \mathrm{kU}_{\mathrm{A}} / \mathrm{L}\right)$, and salmon $\left(3.9 \mathrm{kU}_{\mathrm{A}} / \mathrm{L}\right)$ than at $\mathrm{T} 0\left(16.8 \mathrm{kU}_{\mathrm{A}} / \mathrm{L},[P=.001]\right.$, $18.6 \mathrm{kU}_{\mathrm{A}} / \mathrm{L}[P=.0007], 5.3 \mathrm{kU}_{\mathrm{A}} / \mathrm{L}[P=.004], 5.56 \mathrm{kU}_{\mathrm{A}} / \mathrm{L}$ $[P=.01]$, and $16.15 \mathrm{kU}_{\mathrm{A}} / \mathrm{L}[P=.001]$, respectively). The values were not statistically significant for tuna (Table 4).

The mean wheal diameter in the SPT was larger before patients acquired tolerance for all tested fish as follows: hake, $9.42 \mathrm{~mm}$ vs $3.79 \mathrm{~mm}$; codfish, $9.3 \mathrm{~mm}$ vs $3.4 \mathrm{~mm}$; sardine, $9.0 \mathrm{~mm}$ vs $2.5 \mathrm{~mm}$; and salmon, $7.8 \mathrm{~mm}$ vs $2.8 \mathrm{~mm}$. Despite the fact that all the values were lower after acquiring tolerance, this difference only reached statistical significance for hake $(P=.002)$ and salmon $(P=.026)$ (Table 4$)$.

\section{Discussion}

Despite the fact that females are more likely to become sensitized to fish [1], in the pool of 81 patients included in the present study, most sensitized patients were male $(68 \%, \mathrm{n}=55)$.

As expected, most children and adults included in this study were atopic (75 [92\%]); 78\% had rhinitis, $67 \%$ eczema, and $43 \%$ asthma.

Allergy to fish varies geographically according to the type of diet in different regions of the world, with salmon, tuna, catfish, cod, flatfish, halibut, trout, and sea bass being the most frequent culprits [1]. The most common species associated with allergic reactions in our study mirrored the most frequently consumed species in Portugal, namely, hake (41 [51\%]), mackerel (24 [30\%]), and codfish (21 [26\%]).

As expected, these patients did not present symptoms with fish intake only (78 [96\%]), but also with skin contact (22 [27\%]) and inhalation of cooking vapors (16 [20\%]). Although symptoms associated with the inhalation of vapors were less frequent in the patients we studied, they were reported 
more often than in a group of 197 Spanish children (11\%) [1], where the symptoms after inhalation included dyspnea, wheezing, angioedema of the upper airways, and urticaria [1]. Regardless of the kind of contact with fish, we found the most frequent symptoms to be cutaneous, as expected and previously reported. These were urticaria/angioedema (58 [71\%]), exacerbation of eczema (27 [33\%]), and gastrointestinal symptoms $(28[35 \%])$. Anaphylactic reaction was recorded in 34 patients $(42 \%)$.

In most cases, allergic symptoms were reported after the patient's first contact with fish [1]. In Spain, fish allergy is most frequently diagnosed between 6 and 12 months of age, coinciding with the introduction of fish into the diet [2]. In another Portuguese study, the average age at onset of the first symptoms was between 4 and 12 months [11]. In this study, the average age at the first contact with fish was 9 months, and half of the children presented symptoms compatible with allergic reaction at the first ingestion. While the initial symptoms could be expected to have occurred at around this age, information provided by the parents indicates that the first symptoms occurred at a mean of 24.2 months (mean age for first symptoms, $<18$ years).

Sensitization to individual fish species could be caused by allergens other than parvalbumin $[6,12,13]$. In the present study, only 1 patient was monosensitized (to redfish), probably owing to expression of a protein other than parvalbumin. This case is currently under study.

Of the 81 study patients, 60 acquired tolerance to at least 1 fish species, most frequently tuna (51 [63\%]), likely because of lower concentrations of parvalbumin.

On average, rGad c 1 sIgE was significantly lower once patients had acquired tolerance to at least 1 fish species at $\mathrm{T} 1(5.1 \mathrm{kU} / \mathrm{L})$ when compared with the average value at $\mathrm{T} 0$ $\left(16.9 \mathrm{kU}_{\mathrm{A}} / \mathrm{L}, P=.001\right)$. For all tested fish species, the mean wheal diameter in SPT was lower at T1, although the only significantly lower values were to hake $(9.42 \mathrm{~mm}-3.79 \mathrm{~mm}$; $P=.002)$ and to salmon ( $7.8 \mathrm{~mm}-2.8 \mathrm{~mm} ; P=.026)$. As expected, the same is also true for the mean $\operatorname{sgE}$ values of all fish species tested, and all reached significantly lower values at $\mathrm{T} 1$ except for tuna, possibly because of its reduced allergenicity resulting from the low levels of parvalbumin.

Our data show that parvalbumin SIgE levels and SPT results can probably be considered relevant in the followup of fish-allergic patients. Evaluation of these parameters may help the clinician to decide when to safely perform oral challenge tests in order to confirm acquisition of tolerance and introduce new fish species into a patient's diet. We hypothesize that the SPT wheal diameters for the remaining fish were not statistically significant because of the low number of patients in the study.

Our study was limited by the low number of patients included. Therefore, we believe that prospective studies including a larger number of patients will be required to support our data.

\section{Conclusions}

Fish-allergic patients are often unable to tolerate any species of fish. In this study, the symptoms reported were most frequently associated with hake, which is widely consumed as part of the Mediterranean diet.

In patients with fish allergy, the decrease in serum $\operatorname{sIgE}$ levels for rGad c 1 and the wheal diameter of SPT with hake and salmon could probably be used as prognostic markers for the acquisition of tolerance to fish and may justify future prospective studies using a control group comprising patients who have not acquired tolerance to any species of fish. Overall, tuna was the first and the most widely tolerated fish.

We observed that half of the patients in this study had symptoms on their first contact with fish, thus leading us to assume that sensitization was in utero or associated with breast milk $[15,16]$. However, more studies are warranted to confirm this hypothesis.

\section{Acknowledgments}

We are grateful to Ruben Ferreira, MD, for revising the English in the manuscript.

\section{Funding}

The authors declare that no funding was received for the present study.

\section{Conflicts of Interest}

The authors declare that they have no conflicts of interest.

\section{Previous Presentations}

This study was presented in part as an abstract entitled "Contribution of Recombinant Parvalbumin Gad c 1 in diagnosis and prognosis of fish allergy" at the 2017 annual meeting of the European Academy of Allergy and Clinical Immunology (EAACI) in Helsinki, Finland.

\section{References}

1. Sharp MF, Lopata AL. Fish allergy: In review. Clin Rev Allergy Immunol. 2014;46:258-71.

2. Pascual CY, Reche M, Fiandor A, Valbuena T, Cuevas T, Esteban MM. Fish allergy in childhood. Pediatr Allergy Immunol. 2008;19:573-9.

3. Tsabouri S, Triga M, Makris M, Kalogeromitros D, Church MK, Priftis KN. Fish and shellfish allergy in children: Review of a persistent food allergy. Pediatr Allergy Immunol. 2012;23:60815.

4. Van Do T, Hordvik I, Endresen C, Elsayed S. Characterization of parvalbumin, the major allergen in Alaska pollack, and comparison with codfish Allergen M. Mol Immunol. 2005:42:345-53.

5. Hilger $C$, van Hage M, Kuehn A. Diagnosis of Allergy to Mammals and Fish: Cross-Reactive vs. Specific Markers. Curr Allergy Asthma Rep. 2017;17. doi:10.1007/s11882-0170732-z

6. Tomm JM, van Do T, Jende C, Simon JC, Treudler R, von Bergen $M$, et al. Identification of new potential allergens from nile perch (Lates niloticus) and Cod (Gadus morhua). J Investig Allergol Clin Immunol. 2013;23:159-67. 
7. Kourani E, Corazza F, Michel O, Doyen V. What we know about fish allergy by the end of the decade? I Investig Allergol Clin Immunol. 2019;30:1-23.

8. Van Do T, Elsayed S, Florvaag E, Hordvik I, Endresen C. Allergy to fish parvalbumins: Studies on the cross-reactivity of allergens from 9 commonly consumed fish. J Allergy Clin Immunol. 2005;116:1314-20.

9. Kuehn A, Swoboda I, Arumugam K, Hilger C, Hentges F. Fish allergens at a glance: Variable allergenicity of parvalbumins, the major fish allergens. Front Immunol. 2014;5:1-8.

10. Ruethers T, Taki AC, Johnston EB, Nugraha R, Le TTK, Kalic T, et al. Seafood allergy: A comprehensive review of fish and shellfish allergens. Mol Immunol. 2018;100:28-57.

11. Costa AC, Duarte FC, Trindade JC, Bento ML, dos Santos M da CP. Aquisição de tolerância às proteínas do peixe: Alteração do padrão de sensibilização identificado por immunoblotting. Rev Port Imunoalergologia. 2010;18:353-71.

12. Ebo DG, Kuehn A, Bridts CH, Hilger C, Hentges F, Stevens WJ. Monosensitivity to pangasius and tilapia caused by allergens other than parvalbumin. J Investig Allergol Clin Immunol. 2010;20:84-8.

13. Kondo $Y$, Komatsubara R, Nakajima Y, Yasuda T, Kakami M, Tsuge I, et al. Parvalbumin is not responsible for crossreactivity between tuna and marlin: A case report. J Allergy Clin Immunol. 2006;118:1382-3.
14. Moonesinghe $H$, Mackenzie $H$, Venter $C$, Kilburn S, Turner $P$, Weir $K$, et al. Prevalence of fish and shellfish allergy: A systematic review. Ann Allergy Asthma Immunol. 2016;117:264-72.e4.

15. Pastor-Vargas C, Maroto AS, Díaz-Perales A, Villalba $M$, Esteban V, Ruiz-Ramos $M$, et al. Detection of major food allergens in amniotic fluid: initial allergenic encounter during pregnancy. Pediatr Allergy Immunol. 2016;27:716-20.

16. Pastor-Vargas C, Maroto AS, Díaz-Perales A, Villaba M, Casillas Diaz N, Vivanco F, et al. Sensitive detection of major food allergens in breast milk: first gateway for allergenic contact during breastfeeding. Allergy. 2015;70:1024-7.

\footnotetext{
- Manuscript received May 13, 2019; accepted for publication July 24, 2019.
}

\section{- Sara Patrícia Abreu Carvalho}

Hospital Santa Maria - Centro Hospitalar Universitário Lisboa Norte, Immunoallergology Department

Av. Prof. Egas Moniz

1649-035 Lisboa

E-mail: saracarvalho111@hotmail.com 